\title{
SUBJETIVIDADES RE-INVENTADAS
}

\author{
Andréa Figueiredo Leão Grants \\ Gizelle Kaminski Corso \\ Jair Zandoná \\ Stélio Furlan \\ Tanay Gonçalves Notargiacomo* \\ Universidade Federal de Santa Catarina
}

Autobiografia. Autoficção. Autoria. Escrita. Escritura. Escrita memorialística. Biografia imaginária. Configuração da subjetividade. Diário. Ego-história. Escrita de si. Literatura. História da literatura. Memória. Metaficção historiográfica. Romance. Sujeito. Trágico. Cinema. Adaptação. Este conjunto de palavras-chave reúne, por certo, importantes paratextos que, afora anunciarem a área de interesse privilegiada, acabam por motivar expectativas de leitura no que diz respeito ao que se desenha no presente número do Anuário de Literatura (vol. 17, n. 2).

Considerando as múltiplas possibilidades das escritas de si como mote, a Seção Temática se abre com o artigo Vida de escritura em El Escritor y el otro de Carlos Liscano, de Selomar Claudio Borges, cujo interesse se volta para o movimento de uma prática ficcional a confundir-se com o relato de vida e para as contaminações mútuas advindas desse entrecruzamento. Já Márcio Couto Henrique e Sara da Silva Suliman, em Diário intimo: fonte de pesquisa e instrumento pedagógico, como se depreende do título deste artigo, discorrem sobre as possibilidades de uso do diário íntimo. Os autores se mostram atentos à dimensão social dos diários, e como estes podem ser lidos como registros do diálogo de um indivíduo com o seu tempo e lugar, capazes de propiciar o acesso de pontos de vista diferentes sobre determinados acontecimentos se comparados aos delimitados em fontes históricas oficiais.

EY NC ND Esta obra está licenciada sob uma Licença Creative Commons.

\footnotetext{
* Editores/as da Revista Anuário de Literatura, Programa de Pós-Graduação em Literatura/UFSC.
} 
A escrita historiográfica permeada pela escrita de si: o caso de Como e por que ler o romance brasileiro, título do artigo de Juliana Tomkowski Mesko da Fonseca, centra o foco na obra de Marisa Lajolo lançada em 2004 identificando nela um caso exemplar de como a construção do conhecimento histórico-literário admite a interferência de questões afetivas na mediação dos diversos elementos que o compõe.

Nas relações entre autobiografia e memória reside o objetivo do artigo intitulado $A$ escrita da infância em Graciliano Ramos e Murilo Mendes, de Alinnie Oliveira Andrade Santos. Trata-se de uma análise contrastiva entre os escritores Graciliano Ramos (1892-1953) e Murilo Mendes (1901-1975) com especial atenção à imagem da infância por eles elaborados, em chave confessional, em Infância (1945) e A Idade do Serrote (1969), respectivamente.

Em A relação entre diário e memória em "O Amanuense Belmiro", Aliny Santos Justino aposta no estabelecimento de relações entre diário e memória no texto de Cyro dos Anjos. A autora procura argumentar que o diário se apresenta para o narrador-personagem como um modo de fixação mnemônica das situações do presente que se tornarão memória. Após um diálogo com Maurice Blanchot (1987), o artigo se fecha com uma reflexão sobre a tensa relação existente entre diário e romance na construção da obra. Na sequência, em $O$ eu e o outro da escrita memorialística: um estudo do trágico em "São Bernardo", de Graciliano Ramos, Andréa Trench de Castro analisa a dimensão trágica que permeia o romance São Bernardo, de Graciliano Ramos através do estudo das relações entre memória, escrita, sujeito e verdade.

Identificar a composição do "eu" dentro da ficção de caráter autobiográfico em $O s$ cus de Judas (1979), do escritor português António Lobo Antunes, é o que objetiva o artigo A (des)construção do "eu" n'Os cus de Judas", de Juliana Garcia Santos da Silva. Atenta a voz responsável pela organização do regime do relato, aqui se investiga o desvelamento do "eu" a partir de uma escrita memorialística que retrata o cenário caótico derivado da guerra colonial em Angola.

A Clarice de Ana Miranda, título do artigo de Juliane Cardozo de Mello, trata da ficcionalização de um nome incontornável da literatura brasileira, Clarice Lispector, na novela escrita por Ana Miranda. A autora discute os conceitos de metaficção historiográfica e de biografia imaginária, para destacar que esta reinvenção favorece à Ana Miranda toda uma tessitura de considerações sobre a criação da obra de arte literária, a condição de escritora e de mulher na sociedade. E, encerrando este conjunto de textos concordes ao mote 
privilegiado na seção temática deste número do Anuário de Literatura, vale repetir, as "escritas de si”, em A estratégia da sinceridade em Feliz Ano Velho, de Marcelo Rubens Paiva, Darlan Roberto dos Santos aposta numa reflexão sobre autobiografia. A questão da "verdade" contida na escrita memorialística e as possibilidades de sua elaboração por meio do relato íntimo definem o foco argumentativo deste artigo.

Também compõe este número quatro artigos de temática livre. O primeiro é o artigo A teoria pós-colonial no encontro de duas narrativas, no qual Izabel Cristina dos Santos Teixeira realiza uma leitura comparativa entre duas narrativas - a novela $O$ coração das trevas (1898), de Joseph Conrad e o filme Apocalypse now (1979), do diretor Franz Ford Coppola, como o próprio título indica com fundamentação teórica em pressupostos teóricos oriundos do pós-colonialismo. No segundo artigo, intitulado Função interventiva do coro em “As primícias”, Lourdes Kaminski Alves revela disposição anímica para avaliar a construção da personagem feminina na peça As Primícias (1970), de Dias Gomes. Mas não só. Ao pensar as condições de possiblidade da peça, sem descurar de marcar as diferenças, a autora conclui que a mesma estabelece forte intertextualidade com a tragédia antiga no que se refere à estilização da heroína, à presença das antinomias e à função interventiva do coro.

Investigar a questão do ethos no herói moderno é o que objetiva o artigo intitulado $O$ ethos de Harry Potter a partir da trajetória do herói, de Renato de Oliveira Dering. Recorrendo às teorias de Maingueneau e Vogler sobre o assunto em questão, definindo como corpus de análise privilegiado o livro Harry Potter e a pedra filosofal, o autor avalia em que medida o reconhecimento dos traços arquetípicos do herói em Harry Potter favorece a sua identificação com o leitor compreendido aqui como sujeito ativo no processo de interação com a obra. Enfim, em Reflexões sobre a adaptação cinematográfica de uma obra literária, de Thais Maria Gonçalves da Silva, põe-se em cena uma relação sobredeterminada entre cinema e literatura. Ao dialogar com especialistas no assunto, tais como Jean Epstein (1921) e Arlindo Machado (2007) a autora concede uma atenção especial ao debate sobre o problema de adaptação da obra literária para uma obra cinematográfica.

Espera-se que esta sucinta apresentação dos textos aceitáveis para publicação, agilizada a partir do recorte inicial de palavras-chave, se apresente como convidativa e útil chave de leitura para a compreensão do corpus desta mais recente edição do Anuário de Literatura, periódico que completa, em 2013, vinte anos de existência. Resta agradecer a artista plástica Telma Piacentini por disponibilizar uma das suas mais recentes produções na técnica sumi-ê (nanquim sobre papel) intitulada Outono Kiko, que me evoca uma pequena planta nativa repleta de esporos, bastando um leve sopro para que ela libere suas flores- 
sementes ao sabor dos ventos. Por sinonímia, deseja-se que os textos publicados e agora disseminados em linha possam fecundar diálogos e semear novas afinidades eletivas. Boa leitura!

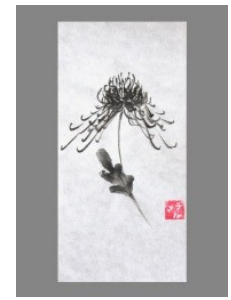

